\title{
Colonization of rare and endangered seeds of plant species cultivated in maintenance breeding at The Living Gene Bank in Jagniątków by microscopic fungi
}

\section{Zasiedlenie przez grzyby mikroskopowe nasion rzadkich i zagrożonych gatunków roślin uprawianych w hodowli zachowawczej w Żywym Banku Genów w Jagniątkowie}

\author{
Wojciech Pusz ${ }^{1 *}$, Marta Kroczek ${ }^{2}$, Agata Kaczmarek ${ }^{1}$
}

\section{Summary}

The aim of the study was to determine the degree of seed colonization by fungi. The seeds were obtained from 11 selected rare plant species cultivated in The Living Gene Bank in Jagniątków (belong to Karkonosze National Park): Aconitum plicatum, Allium sibiricum, Anemone alpina, Arabis alpina, Campanula bohemica, Drosera rotundifolia, Geum montanum, Pimpinella saxifraga subsp. rupestris, Rhodiola rosea, Saxifraga moschata subsp. basaltica, Saxifraga nivalis. The mycological analysis revealed that the seeds were colonized by 23 species of fungi. Alternaria alternata was the most frequently isolated species from the non-disinfected seeds. The surface decontamination of seeds with sodium hypochlorite significantly reduced the number of obtained fungal colonies, and in the case an increase of the number of germinated seeds was recorded for A. sibiricum and S. moschata subsp. basaltica.

Key words: spermosphaere; fungi; rare plant species; gene bank; preservative breeding

\section{Streszczenie}

Celem przeprowadzonych badań było określenie stopnia zasiedlenia przez grzyby nasion wybranych gatunków rzadkich roślin uprawianych w Żywym Banku Genów w Jagniątkowie (należącym do Karkonoskiego Parku Narodowego). Materiałem do analizy mykologicznej były nasiona 11 gatunków roślin: Aconitum plicatum, Allium sibiricum, Anemone alpina, Arabis alpina, Campanula bohemica, Drosera rotundifolia, Geum montanum, Pimpinella saxifraga subsp. rupestris, Rhodiola rosea, Saxifraga moschata subsp. basaltica, Saxifraga nivalis. W trakcie analizy mykologicznej stwierdzono, że nasiona były zasiedlone przez 23 gatunki grzybów. W przypadku nasion nieodkażonych największym udziałem charakteryzował się gatunek Alternaria alternata. Odkażanie nasion podchlorynem sodu znacznie zmniejszyło liczbę uzyskanych kolonii grzybów, a w przypadku A. sibiricum oraz S. moschata subsp. basaltica wpłynęło na wzrost liczby skiełkowanych nasion.

Słowa kluczowe: spermosfera; grzyby; rzadkie gatunki roślin; bank genów; hodowla zachowawcza

\footnotetext{
${ }^{1}$ Uniwersytet Przyrodniczy we Wrocławiu Katedra Ochrony Roślin

pl. Grunwaldzki 24A, 50-363 Wrocław

${ }^{2}$ Karkonoski Park Narodowy

Chałubińskiego 23, 58-570 Jelenia Góra

*corresponding author: wojciech.pusz@up.wroc.pl
} 


\section{Wstęp / Introduction}

Karkonosze są stosunkowo niskim pasmem gór (najwyższy szczyt - Śnieżka o wysokości 1602 m n.p.m.), lecz wiekowo starym i zerodowanym, które zostało wydźwignięte w okresie fałdowania alpejskiego (Szczęśniak i wsp. 2009). Między innymi ten fakt wpłynął na powstanie enklaw wysokogórskich, cechujących się dużą skalistością oraz kotłów polodowcowych, gdzie występują rzadkie i bardzo rzadkie gatunki roślin, zaliczane do reliktów glacjalnych oraz endemitów (Chlebicki 2002; Szczęśniak i wsp. 2009; Dworzycki i Kroczek 2013).

W ostatnich dziesięcioleciach obserwuje się w Karkonoszach spadek liczebności populacji rzadkich gatunków roślin, który w skrajnych sytuacjach może doprowadzić do ich zamierania (Żołnierz i wsp. 2004). Zagrożone są gatunki, które świadczą o wyjątkowości Karkonoszy, w tym endemity, jak np. Campanula bohemica oraz relikty glacjalne, tj. Allium sibiricum, Arabis alpina, Geum montanum czy też gatunki rodzaju Saxifraga: S. nivalis, S. moschata (Mirek i wsp. 2002; Żołnierz i wsp. 2004; Szczęśniak i wsp. 2009). Jeszcze gorzej przedstawia się sytuacja, gdy porównywane są obecnie prowadzone analizy florystyczne $\mathrm{z}$ tymi historycznymi (Fabiszewski i Kwiatkowski 2002). Dlatego też w Karkonoskim Parku Narodowym (KPN) prowadzone są od wielu lat różnego rodzaju przedsięwzięcia, których nadrzędnym celem jest zahamowanie tego procesu oraz ochrona zarówno siedlisk, jak i samych gatunków zagrożonych wymarciem. Jednym z takich działań było stworzenie w 2010 roku Żywego Banku Genów KPN w Jagniątkowie. Zadaniem Banku jest zabezpieczenie zasobów genowych rzadkich i zagrożonych gatunków roślin występujących w Karkonoszach oraz opracowanie metodyki uprawy, a następnie hodowli ex situ oraz ich ewentualnej reintrodukcji (Dworzycki i Kroczek 2013).

Jednym z największych problemów, z jakimi borykają się przyrodnicy w Żywym Banku Genów jest niski procent skiełkowanych nasion, co ma bezpośredni wpływ na dalszą hodowlę zachowawczą gatunków roślin, nie mówiąc już o ich reintrodukcji na stanowiskach naturalnych (Dworzycki i Kroczek 2013).

Celem przeprowadzonych badań było określenie stopnia zasiedlenia nasion wybranych gatunków roślin przez grzyby.

\section{Materiały i metody / Materials and methods}

Materiałem do analizy mykologicznej były nasiona 11 gatunków roślin: Aconitum plicatum (tojad sudecki), Allium sibiricum (czosnek syberyjski), Anemone alpina (sasanka alpejska), Arabis alpina (gęsiówka alpejska), Campanula bohemica (dzwonek karkonoski), Drosera rotundifolia (rosiczka okrągłolistna), Geum montanum (kuklik górski), Pimpinella saxifraga subsp. rupestris (biedrzeniec mniejszy), Rhodiola rosea (różeniec górski), Saxifraga moschata subsp. basaltica (skalnica bazaltowa), Saxifraga nivalis (skalnica śnieżna) zaliczanych według IUCN (International Union for Conservation of Nature Międzynarodowa Unia Ochrony Przyrody) (2001) do kate- gorii CR (critically endangered - krytycznie zagrożony), EN (endangered - zagrożony wyginięciem) oraz VU (vulnerable - narażony).

Nasiona zostały zebrane ze stanowisk naturalnych (Wielki Śnieżny Kocioł, Mały Śnieżny Kocioł) we wrześniu i październiku 2013 roku. Następnie przechowywane były w ciemności, w sterylnych kopertach papierowych w temperaturze $20-20^{\circ} \mathrm{C}$. Pierwszą analizę wykonano 6 tygodni po zbiorze nasion (I termin). Kolejną analizę wykonano po półrocznym okresie przechowywania (II termin), a ostatnia analiza przypadła na okres około 18 miesięcy po zbiorze (III termin).

Nasiona zostały podzielone na dwie partie: jedna $\mathrm{z}$ nich (obejmująca nasiona 11 gatunków roślin) została wyłożona bezpośrednio na szalki Petriego z $2 \%$ zestaloną pożywką maltozową. Z powodu małej liczby uzyskanych nasion odkażono powierzchniowo nasiona 5 gatunków roślin (A. plicatum, A. sibiricum, A. alpina, G. montanum, $P$. saxifraga subsp. rupestris) przed wyłożeniem na pożywkę $1 \%$ roztworem podchlorynu sodu przez 30 sekund. Wyrastające $\mathrm{z}$ nasion kolonie grzybów oznaczono do gatunku na podstawie cech morfologicznych (Pitt i Hocking 2009; Watanabe 2011).

Dodatkowo, po 18 miesięcznym okresie przechowywania, określono zdolność i energię kiełkowania nasion zgodnie z zalecaną przez Lasy Państwowe metodyką do oceny przedsiewnej nasion (Załęski 2000). Nasiona: A. plicatum, A. sibiricum, D. rotundifolia, G. montanum, $P$. saxifraga subsp. rupestris, $R$. rosea, $S$. moschata subsp. basaltica, $S$. nivalis zostały również poddane działaniu $1 \%$ podchlorynu sodu przez 30 sekund, aby określić ewentualny wpływ stosowania tego zabiegu na ich zdolność i energię kiełkowania.

Ze względu na różną dostępność nasion badanych gatunków roślin zmienna była liczba nasion (w zależności od gatunku rośliny od 30 do 50 sztuk) oraz liczba samych gatunków roślin. Biorąc jednak pod uwagę pionierski charakter tych badań, można uznać, że badane próby były reprezentatywne i oddają zaistniały stan rzeczy.

\section{Wyniki i dyskusja / Results and discussion}

W trakcie analizy mykologicznej stwierdzono, że nasiona są zasiedlone przez 23 gatunki grzybów. W przypadku nasion nieodkażonych największym udziałem charakteryzował się gatunek Alternaria alternata. Wyjątkiem były nasiona $A$. plicatum, gdzie dominował Truncatella hartigii (44,2\% wszystkich wyizolowanych grzybów); A. sibiricum z dominantem Arthinium pheospermum (stanowił 37,9\% wszystkich wyosobnionych gatunków); C. bohemica, gdzie Cladosporium cladosporioides stanowił $38,1 \%$ ogółu uzyskanych kolonii. Natomiast w przypadku G. montanum największym udziałem charakteryzował się gatunek Botrytis cinerea, który stanowił 42,9\% ogółu wyosobnionych gatunków (tab. 1a, b).

Wśród grzybów wyizolowanych z nasion odkażonych A. alternata dominował w spermosferze $A$. plicatum $(64,5 \%)$ oraz $P$. saxifraga $(81,9 \%)$. W przypadku $A$. sibiricum zaistniała identyczna sytuacja, jak w wariancie $\mathrm{z}$ nasionami nieodkażonymi - większość stanowił $A$. phe- 


\begin{tabular}{|c|c|c|c|c|c|c|c|c|c|c|c|c|c|c|c|c|c|c|c|c|c|c|c|c|}
\hline \multirow{4}{*}{ 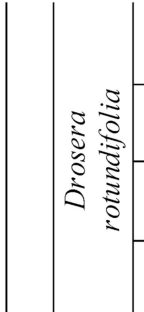 } & \multicolumn{2}{|c|}{$a^{\circ}$} & $\begin{array}{l}\infty \\
\stackrel{1}{=}\end{array}$ & & & & & & & & & & $\ddot{n}$ & m & $n$ & $\ddot{n}$ & જे & & $\begin{array}{l}\stackrel{2}{\simeq} \\
=\end{array}$ & & & & $\bar{f}$ & 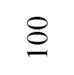 \\
\hline & $\Xi$ & 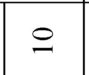 & - & & & & & & & & & & & & - & - & & & & & & & $r$ & 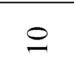 \\
\hline & $=$ & 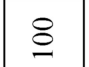 & $\mathrm{N}$ & & & & & & & & & & - & - & & & & & in & & & & 0 & $\cong$ \\
\hline & - & 0 & N & & & & & & & & & & & & & & $N$ & & & & & & & $\nabla$ \\
\hline \multirow{8}{*}{$\begin{array}{l}\frac{0}{0} \\
\frac{0}{0} \\
\frac{2}{n} \\
\frac{1}{0} \\
\frac{0}{2} \\
1\end{array}$} & & $\therefore^{\circ}$ & $\overrightarrow{\vec{v}}$ & ते & & & ले & & $\overline{\dot{m}^{0}}$ & & $\widehat{\grave{i}}$ & $\hat{\vec{i}}$ & & & & & $\hat{o}$ & $\stackrel{2}{2}$ & & & & $\hat{o}$ & $\stackrel{1}{2}$ & 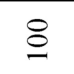 \\
\hline & $\exists$ & $\cong$ & $r$ & + & & & & & $=$ & & $m$ & & & & & & - & N & & & & & $m$ & $\hat{m}$ \\
\hline & $=$ & 's & $\stackrel{\sim}{\sim}$ & $N$ & & & $\nabla$ & & - & & & $m$ & & & & & & & & & & & 0 & i \\
\hline & - & 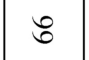 & - & & & & & & $\bar{N}$ & & & & & & & & & & & & & - & 0 & ते \\
\hline & & $\partial^{\circ}$ & $\vec{g}$ & $\stackrel{m}{=}$ & & & $\nabla$ & & $\stackrel{2}{=}$ & $\hat{i}$ & & $\stackrel{2}{=}$ & & & $?$ & & $\hat{i}$ & & & & & & & $\cong$ \\
\hline & $\equiv$ & in & $\mathrm{N}$ & & & & & & $\simeq$ & & & & & & & & - & & & & & & & $\because$ \\
\hline & $=$ & $£$ & q & & & & $m$ & & - & & & - & & & - & & - & & & & & & & F \\
\hline & - & $\stackrel{\infty}{\sim}$ & 이 & - & & & & & & $N$ & & & & & & & & & & & & & & 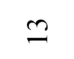 \\
\hline \multirow{4}{*}{ 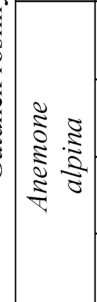 } & & $\therefore^{\circ}$ & $\underset{f}{f}$ & & & & 定 & & & & $\stackrel{0}{i}$ & $\cong$ & $\begin{array}{c}\infty \\
i \\
i n\end{array}$ & & & & & & & $\overline{0}$ & & & & $£$ \\
\hline & $\equiv$ & 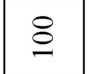 & $\ddot{m}$ & & & & & & & & - & $\sim$ & & & & & & & & $=$ & & & & in \\
\hline & $=$ & 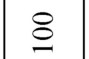 & - & & & & $\stackrel{2}{a}$ & & & & & & $r$ & & & & & & & & & & & $m$ \\
\hline & - & in & $\Xi$ & & & & $\sigma$ & & & & $\sim$ & & & & & & & & & $N$ & & & & in \\
\hline \multirow{4}{*}{ 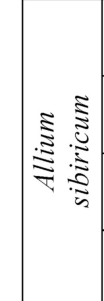 } & & $\partial^{\circ}$ & $\hat{\sigma}$ & $\stackrel{\infty}{-}$ & $\frac{a}{m}$ & & $\begin{array}{l}\infty \\
\stackrel{\sim}{\sim}\end{array}$ & $\hat{\sigma}$ & & & $\hat{\sigma}$ & $\begin{array}{c}n \\
\infty\end{array}$ & & & & & & & $\begin{array}{c}1 \\
\infty\end{array}$ & $\stackrel{\infty}{-}$ & & & $\begin{array}{l}0 \\
\infty \\
\infty\end{array}$ & 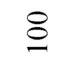 \\
\hline & $\Xi$ & $\cong$ & & & F & & - & & & & - & & & & & & & & 0 & $\mathrm{~N}$ & & & & in \\
\hline & $=$ & 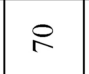 & - & $\sim$ & & & N & - & & & & $a$ & & & & & & & $m$ & & & & $\sim$ & $\stackrel{i}{ }$ \\
\hline & - & $\stackrel{\sim}{\sim}$ & & & & & $\stackrel{\sim}{ }$ & & & & & & & & & & & & & & & & 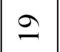 & ले \\
\hline \multirow{4}{*}{ 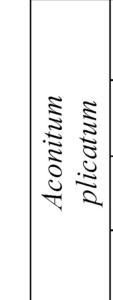 } & & $\therefore$ & $\begin{array}{r}\mathcal{H} \\
\mathcal{f}\end{array}$ & & & $\hat{\sigma}$ & $\hat{i}$ & & $\overrightarrow{\mathrm{i}}$ & & & & & & $\ddot{\theta}$ & & $\hat{o}$ & & $\hat{\mathrm{i}}$ & $\stackrel{?}{-}$ & $\hat{\sigma}_{0}$ & $\begin{array}{l}N \\
f\end{array}$ & & 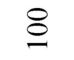 \\
\hline & $\equiv$ & $\cong$ & & & & & & & $m$ & & & & & & & & - & & & $\mathrm{N}$ & & ' & & $\bar{n}$ \\
\hline & $=$ & 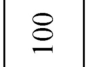 & $\mathscr{q}$ & & & & $m$ & & & & & & & & & & & & $m$ & - & - & & & $\bar{n}$ \\
\hline & - & $\cong$ & $\exists$ & & & - & $m$ & & & & & & & & - & & - & & & - & & & & $\bar{n}$ \\
\hline 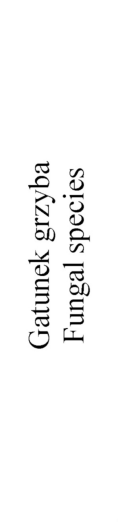 & & 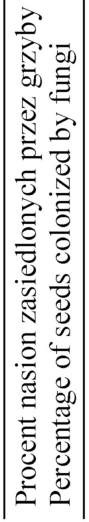 & 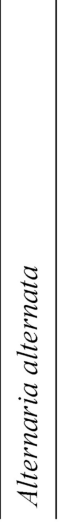 & 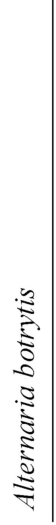 & 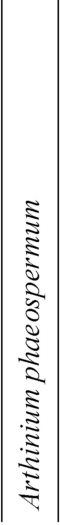 & 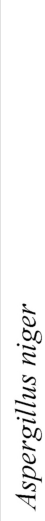 & 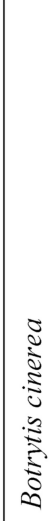 & 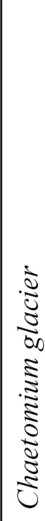 & 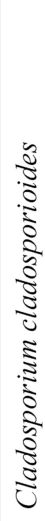 & 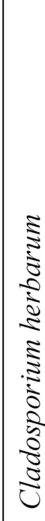 & 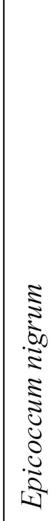 & 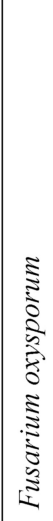 & 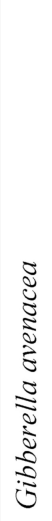 & 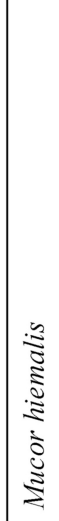 & 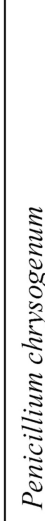 & 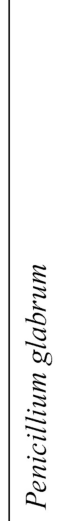 & 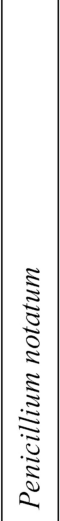 & 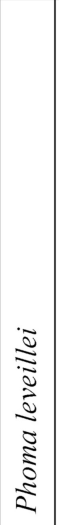 & 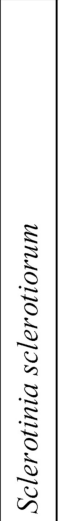 & 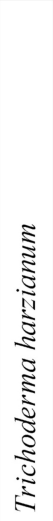 & 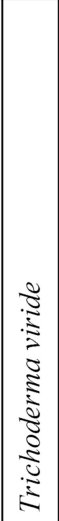 & 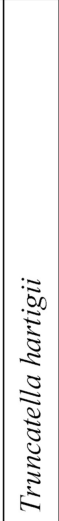 & 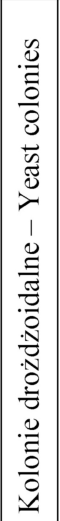 & 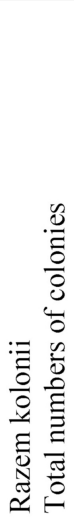 \\
\hline
\end{tabular}




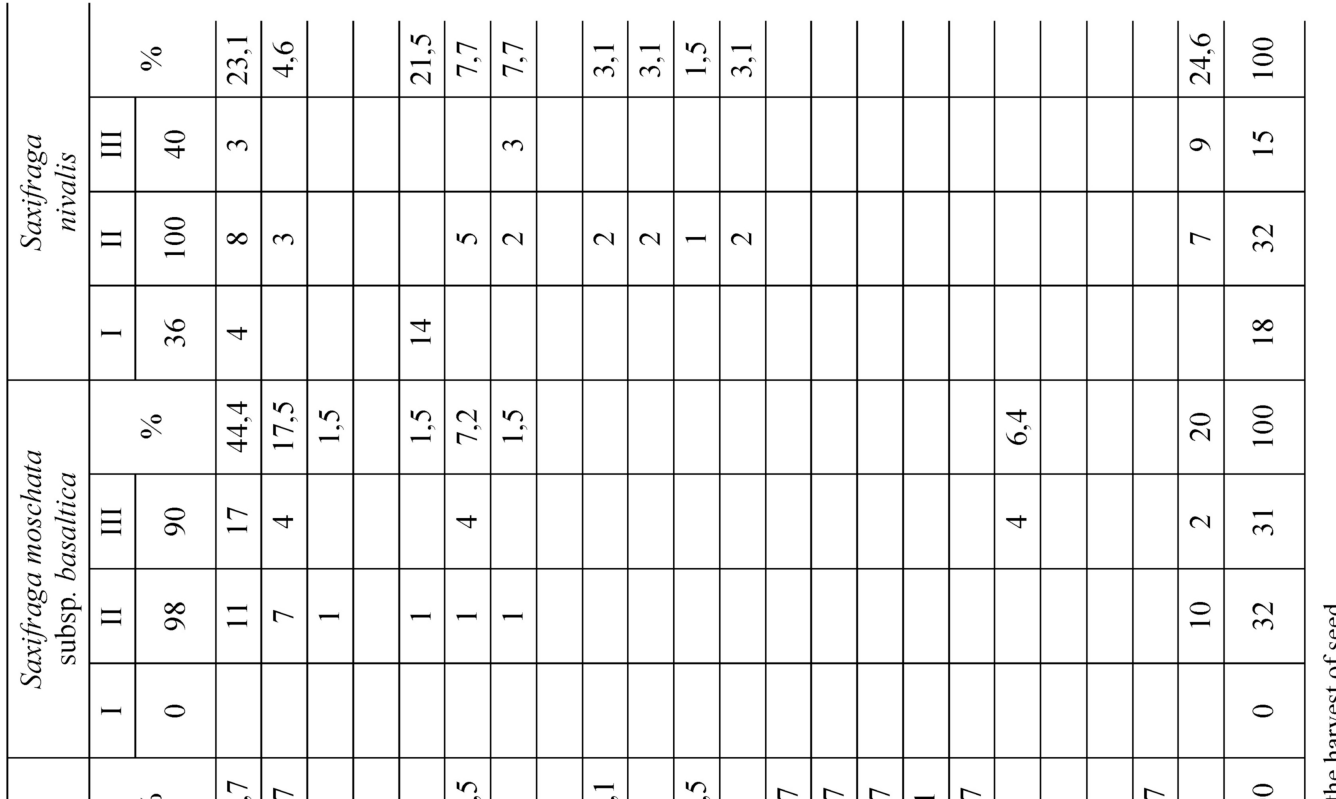

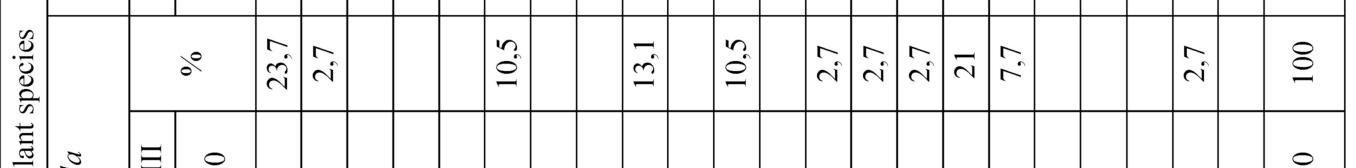

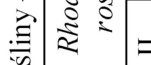

$\cong r-$

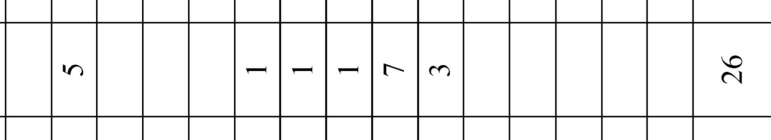

急

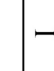

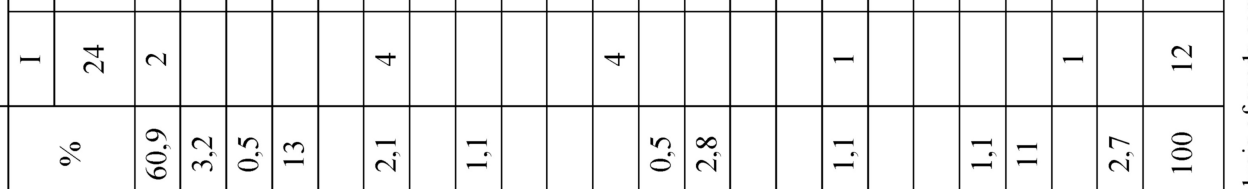

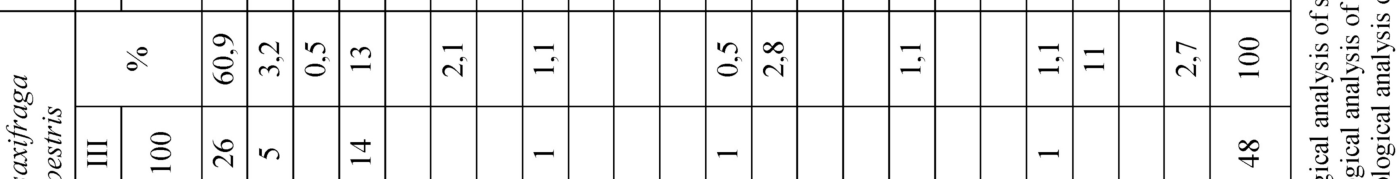

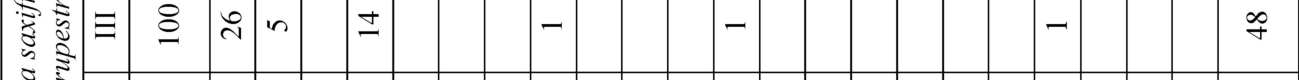

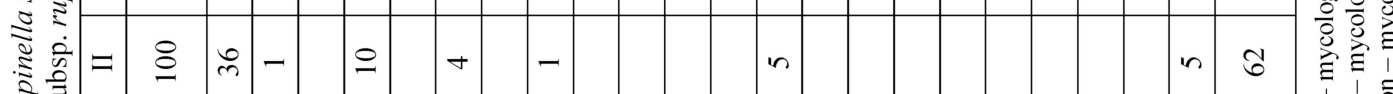
ミ

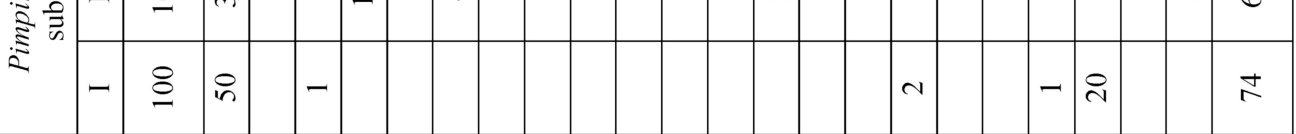
害 政 它解 6 늘 흘 ठ․ 0

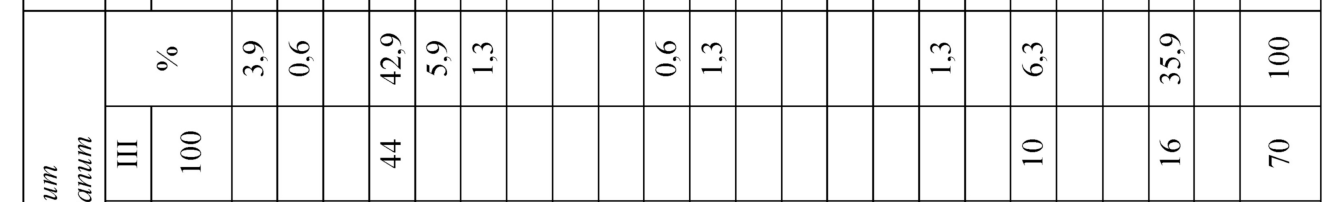
흔.

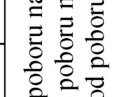

\begin{tabular}{|c|c|c|c|c|c|c|c|c|c|c|c|c|c|c|c|c|c|c|c|c|c|c|c|}
\hline \multirow{3}{*}{ 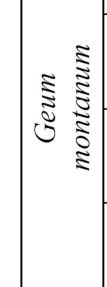 } & $\Xi$ & $\nsubseteq$ & & & & 寸 & & & & & & & & & & & & 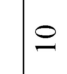 & & & 2 & $\stackrel{R}{R}$ & \\
\hline & $=$ & 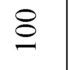 & & - & & 는 & & $N$ & & & - & $-\lambda$ & & & & & & & & $\exists$ & \pm & ల & \\
\hline & - & $\nsubseteq$ & 0 & & & in & $a$ & & & & & & & & & & $\sim$ & & & & 2 & F & \\
\hline 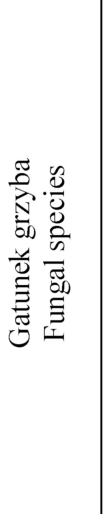 & & 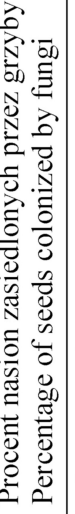 & 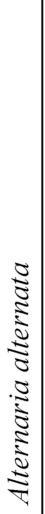 & 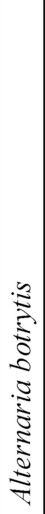 & 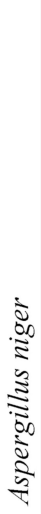 & 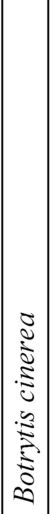 & & 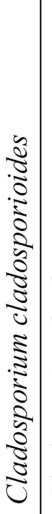 & 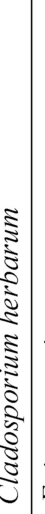 & 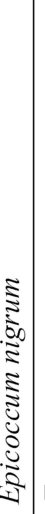 & 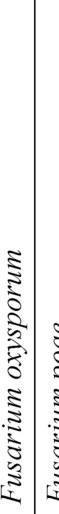 & 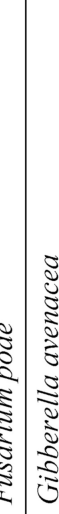 & 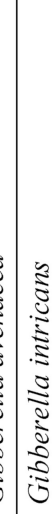 & 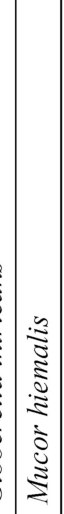 & 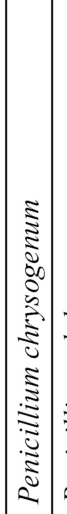 & 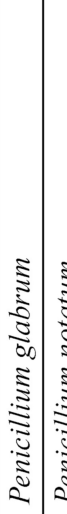 & 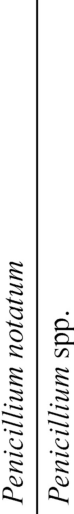 & 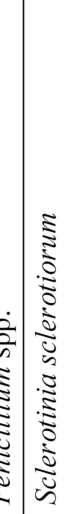 & 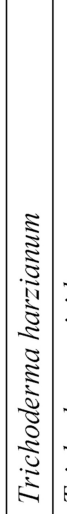 & 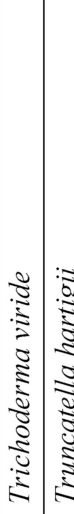 & 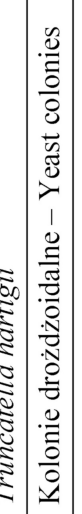 & 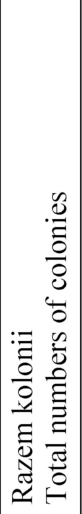 & \\
\hline
\end{tabular}




\begin{tabular}{|c|c|c|c|c|c|c|c|c|c|c|c|c|c|c|c|c|c|}
\hline \multirow{4}{*}{ 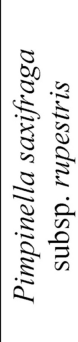 } & \multicolumn{2}{|c|}{$\partial^{\circ}$} & $\frac{a}{\infty}$ & $\vec{i}$ & $\stackrel{ \pm}{-}$ & & $\hat{o}$ & & $\vec{i}$ & $\hat{\sigma}_{0}$ & $\stackrel{\gamma}{\gamma}$ & & & & & & \\
\hline & $\Xi$ & 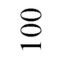 & तี & $m$ & & & & & $N$ & $\infty$ & $r$ & & & & & & F \\
\hline & $=$ & $£$ & in & & & & - & & & & & & & & & & in \\
\hline & - & $\nsubseteq$ & $\mathscr{f}$ & & $\sim$ & & & & - & $N$ & & & & & & & $\checkmark$ \\
\hline & & $\therefore$ & $\infty_{\infty}^{2}$ & $\bar{f}$ & $\bar{m}$ & $\begin{array}{l}\hat{\alpha} \\
\text { iे }\end{array}$ & $=$ & $\begin{array}{l}0 \\
\infty \\
\infty\end{array}$ & & & & $\vec{i}$ & $\bar{m}$ & $\bar{i}$ & $\Xi$ & $\begin{array}{l}\infty \\
\stackrel{\sim}{N}\end{array}$ & \& \\
\hline ฐ & $\Xi$ & $\nsubseteq$ & in & $N$ & - & $\sim$ & & $\simeq$ & & & & & & $N$ & & $=$ & \\
\hline
\end{tabular}

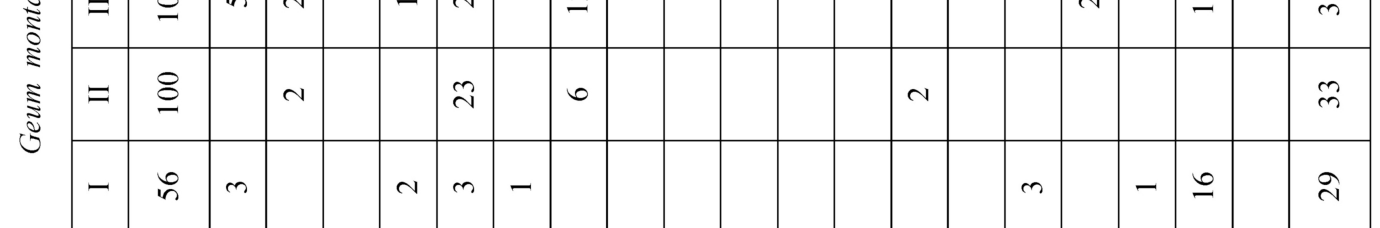

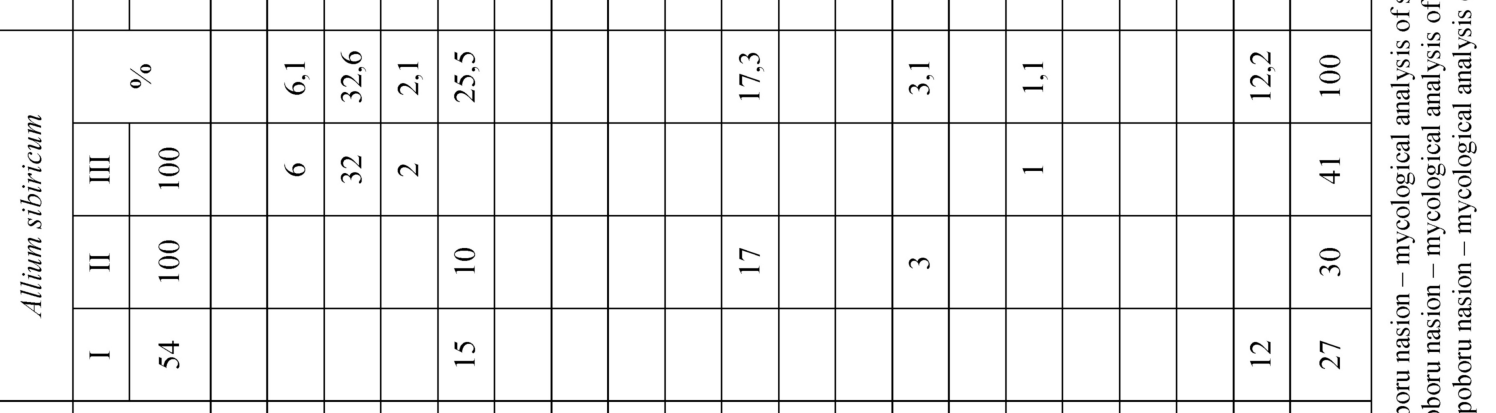

\begin{tabular}{|c|c|c|c|c|c|c|c|c|c|c|c|c|c|c|c|c|c|c|c|c|c|c|c|}
\hline & & e & $\begin{array}{l}n \\
\text { fo }\end{array}$ & & & $\stackrel{0}{-}$ & $\begin{array}{l}\infty \\
\approx \\
n\end{array}$ & $\stackrel{0}{-}$ & $\stackrel{0}{-}$ & & $\stackrel{0}{-}$ & & & & & $m$ & & & & & & $\nsubseteq$ & $\because 0$ \\
\hline 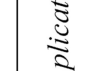 & $\Xi$ & 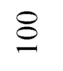 & $\bar{N}$ & & & & $\mathscr{0}$ & & & & - & & & & & & & & & & & $\infty$ & 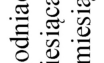 \\
\hline 离 & $=$ & in & $=$ & & & & & - & - & & & & & & & & & & & & & $\stackrel{2}{ }$ & \\
\hline & - & 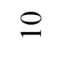 & $N$ & & & - & & & & & & & & & & $N$ & & & & & & in & \\
\hline 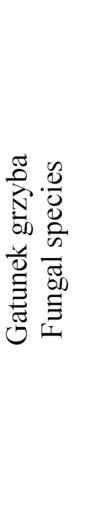 & & 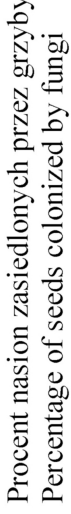 & 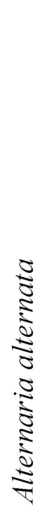 & 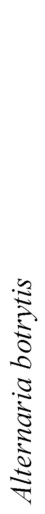 & 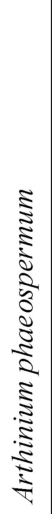 & 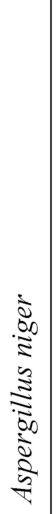 & 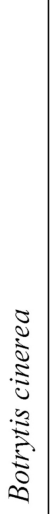 & 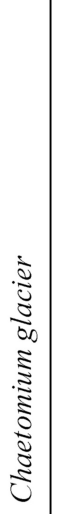 & 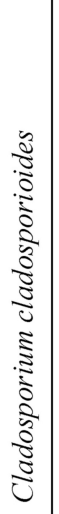 & 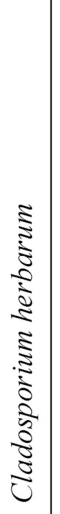 & 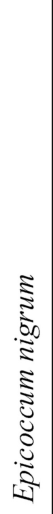 & 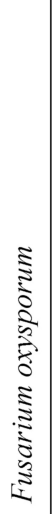 & 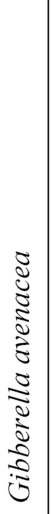 & 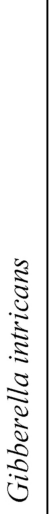 & 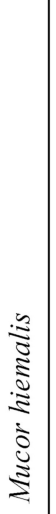 & 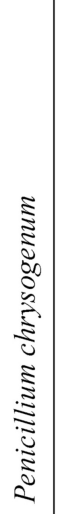 & 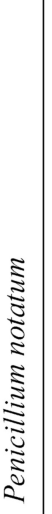 & 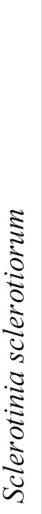 & 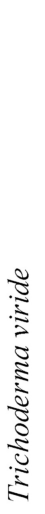 & 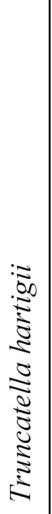 & 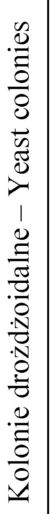 & 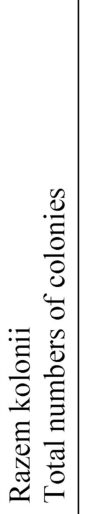 & 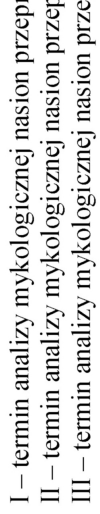 \\
\hline
\end{tabular}




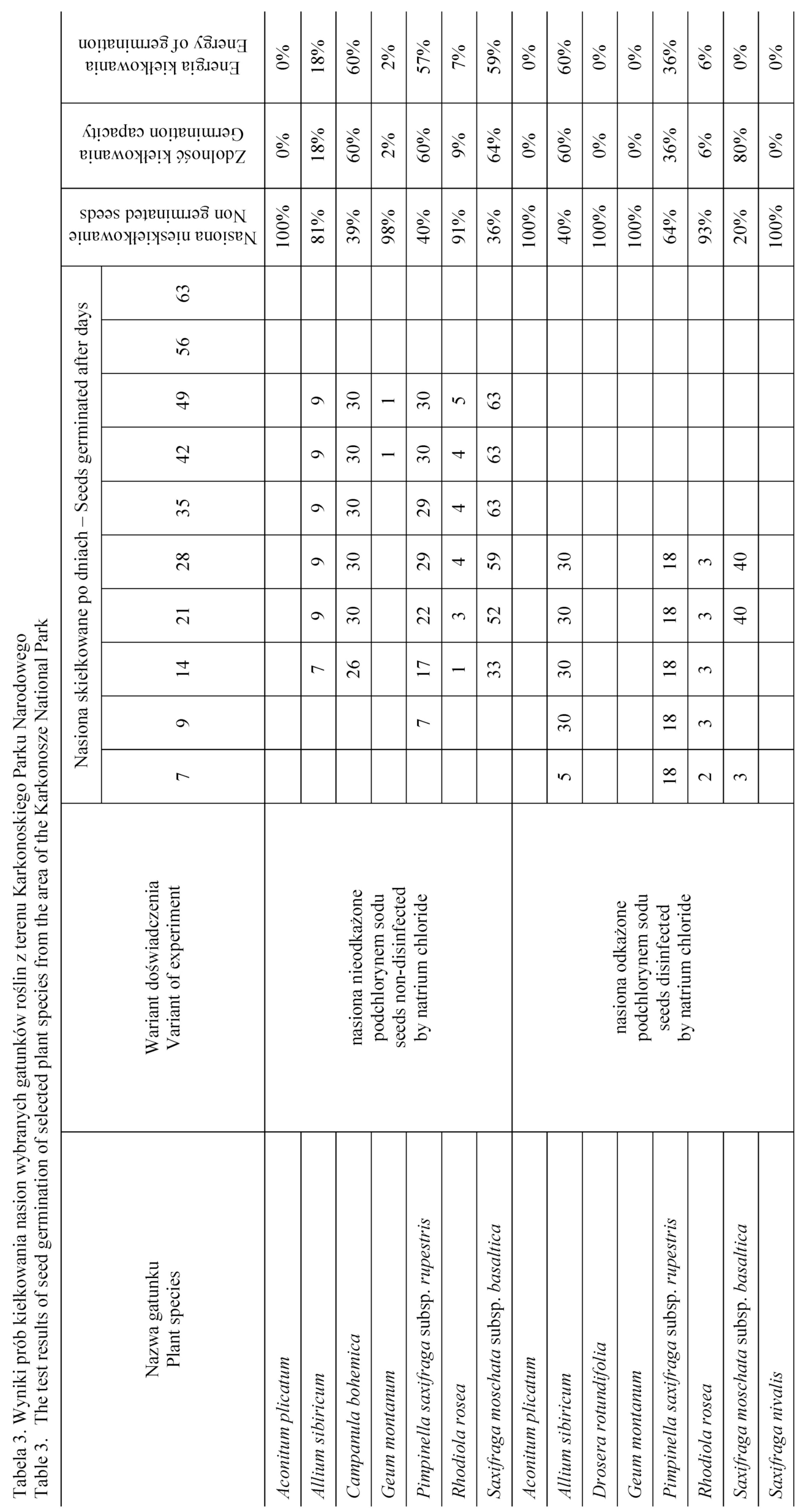


ospermum (32,6\%). Natomiast grzyb Chaetomium glacier był dominantem zasiedlającym nasiona $A$. alpina $(47,7 \%)$, a B. cinerea $(28,9 \%)-G$. montanum (tab. 2$)$.

$\mathrm{Z}$ nasion większości badanych gatunków roślin licznie wyizolowano $A$. alternata. Gatunek ten wyosabniano zarówno $\mathrm{z}$ nasion nieodkażonych, jak i odkażonych podchlorynem sodu, co świadczy o trwałym, wewnętrznym penetrowaniu nasion przez grzybnię. Wyniki autorów potwierdzają wcześniejsze doniesienia dotyczące nasion innych roślin (Jajor 2006). Występowanie A. alternata na przechowywanych nasionach nie zawsze świadczy o złej jakości materiału siewnego (Pusz 2009), co znajduje swoje potwierdzenie $\mathrm{w}$ określaniu zdolności kiełkowania badanych nasion. W przypadku nasion $P$. saxifraga subsp. rupestris oraz $S$. moschata subsp. basaltica, gdzie $A$. alternata stanowił zdecydowaną większość wśród wszystkich wyosobnionych grzybów, stwierdzono do około $40 \%$ nieskiełkowanych nasion, gdy np. w przypadku A. plicatum było to $100 \%$, G. montanum $-98 \%$, a $R$. rosea blisko $91 \%$ (tab. 3). Tylko nasiona tego ostatniego gatunku były zasiedlone w największym stopniu przez A. alternata. Grzyb ten jest uważany za typowego przedstawiciela spermosfery i może być uwzględniany jako jeden ze wskaźników złej jakości nasion (Logrieco i wsp. 2009). Jednak inni uważają, że to głównie grzyby rodzaju Fusarium znacznie obniżają jakość nasion (Jajor 2006; Pusz 2009; Kordas i wsp. 2015). W przeprowadzonym doświadczeniu Fusarium spp. w największym stopniu zasiedlały nasiona $A$. sibiricum, A alpina oraz $R$. rosea. Podobna sytuacja miała miejsce w przypadku $B$. cinerea, który licznie zasiedlając nasiona $A$. sibiricum, $G$. montanum oraz $P$. saxifraga subsp. rupestris znacznie obniżył ich wigor. Uzyskane wyniki znajdują potwierdzenie w pracach innych badaczy (Jajor 2006).

Odkażenie nasion podchlorynem sodu znacznie zmniejszyło liczbę uzyskanych kolonii grzybów. Potwierdzają to badania innych autorów, którzy zaobserwowali, że odkażanie powierzchniowe pozwala określić stopień zasiedlenia wnętrza nasiona przez grzyby ( $\mathrm{Xu}$ i Nicholson 2009). Okazało się, że niektóre grzyby występują zarówno na powierzchni, jak i wnikają do wnętrza nasiona, co znacznie wpływa na ich jakość. Taka sytuacja miała miejsce w przypadku $A$. sibiricum, gdzie zarówno powierzchnia, jak i wnętrze nasion były zasiedlone w największym stopniu przez $A$. pheospermum. W trakcie badań wigoru nasion stwierdzono, że aż $81 \% \mathrm{z}$ nich nie skiełkowało. Negatywny wpływ tego gatunku na nasiona znajduje swoje potwierdzenie w badaniach innych autorów (Niaz i Dawar 2009). Z kolei w przypadku nasion $A$. plicatum, powierzchniowe odkażenie wykazało, że wnętrze badanego materiału jest zasiedlone w dużym stopniu przez
A. alternata oraz B. cinerea. Ten drugi gatunek jest zdolny do zasiedlania wnętrza tkanek, co stwierdzono w przypadku $A$. sibiricum, A. alpina oraz $G$. montanum. B. cinerea jest pospolitym patogenem wielu gatunków roślin i wpływa negatywnie zarówno na wigor nasion, jak i wzrost oraz rozwój roślin (Sowley i wsp. 2010).

$\mathrm{Na}$ kiełkowanie nasion oprócz stopnia zasiedlenia przez grzyby mają także wpływ inne czynniki, jak np. termin zbioru nasion czy też wilgotność (Magan i wsp. 2010). Znaczenie może mieć także odkażanie powierzchniowe, którego celem jest ograniczenie zasiedlenia nasion przez grzyby. Okazało się, że tylko w przypadku $A$. sibiricum oraz $S$. moschata subsp. basaltica zastosowanie podchlorynu sodu jako środka odkażającego nie wpłynęło na zwiększenie liczby skiełkowanych nasion (tab. 3). Interesujący jest również fakt, że nasiona potraktowane podchlorynem sodu znacznie szybciej kiełkowały niż nasiona nieodkażane. Zwiększenie liczby skiełkowanych nasion po ich odkażeniu podchlorynem sodu znajduje swoje potwierdzenie w pracach innych autorów (Weiner i Domaradzka 2005).

Rozpatrywany problem zasiedlenia nasion rzadkich gatunków roślin i zagrożonych wyginięciem jest tematyką, która wpisuje się doskonale w ochronę rzadkich gatunków roślin oraz podejmowanych prób ich reintrodukcji i hodowli zachowawczej (Cooper i wsp. 2004; Alsos i wsp. 2013; Dworzycki i Kroczek 2013). Analizy mykologiczne nasion powinny być przeprowadzane standardowo, a ich wyniki mogą być wykorzystane przez służby ochrony przyrody.

\section{Wnioski / Conclusions}

1. Nasiona rzadkich i zagrożonych gatunków roślin uprawianych w ramach hodowli zachowawczej w Żywym Banku Genów w Jagniątkowie są w znacznym stopniu zasiedlone przez grzyby, co może być spowodowane nieodpowiednim terminem zbioru nasion oraz ich przechowywaniem.

2. Odkażanie powierzchniowe nasion podchlorynem sodu ogranicza liczbę kolonii grzybów.

3. W przypadku A. sibiricum oraz S. moschata subsp. basaltica odkażanie powierzchniowe podchlorynem sodu wpłynęło na wzrost liczby skiełkowanych nasion.

4. Konieczne jest określenie dokładnego terminu zbioru nasion poszczególnych gatunków roślin.

Praca finansowana przez Fundusz Leśny Państwowego Gospodarstwa Leśnego „Lasy Państwowe”.

\section{Literatura / References}

Alsos I.G., Muller E., Eidesen P.B. 2013. Germinating seeds or bubils in 87 of 113 tested Arctic species indicating potential for ex situ seed bank storage. Polar Biology 36 (6): 819-830.

Chlebicki A. 2002. Biogeographic relationships between fungi and selected glacial relict plants. Monographiae Botanicae vol. 90 . Polish Botanical Society, Warszawa, $233 \mathrm{pp}$.

Cooper E.J., Alsos I.G., Hagen D., Smith F.M., Coulson S.J., Hodkinson I.D. 2004. Plant recruitment in the High Arctic: seed bank and seedling emergence on Svalbard. Journal of Vegetation Science 15 (1): 115-124. 
Dworzycki K., Kroczek M. 2013. Próby kiełkowania nasion rzadkich i zagrożonych gatunków roślin z terenu Karkonoskiego Parku Narodowego. Opera Corcontica 50: 27-34.

Fabiszewski J., Kwiatkowski P. 2002. Threatened vascular plants of the Sudeten Mountains. Acta Societatis Botanicorum Poloniae 71 (4): 339-350.

IUCN 2001. IUCN Red List Categories and Criteria (Version 3.1). http://www.iucn.org/themes/ssc/redlist/RLcats2001.booklet.html [Accessed: 05.10.2015].

Jajor E. 2006. Zasiedlenie przez grzyby nasion odmian populacyjnych i mieszańcowych rzepaku pochodzących ze zbioru 2004 roku. [Colonisation of seeds of open-pollinated and hybrid oilseed rape cultivars from 2004 harvest]. Progress in Plant Protection/Postępy w Ochronie Roślin 46 (2): 572-575.

Kordas L., Pusz W., Czapka T., Kacprzyk R. 2015. The effect of low-temperature plasma on fungus colonization of winter wheat grain and on seed quality. Polish Journal of Environmental Studies 24 (1): 433-438.

Logrieco A., Moretti A., Solfrizzo M. 2009. Alternaria toxins and plant diseases: an overview of origin, occurrence and risks. World Mycotox Journal 2 (2): 129-140.

Magan N., Aldred D., Mylona K., Lambert R.J.W. 2010. Limiting mycotoxins in stored wheat - a review. Food Additives and Contaminants 27 (05): 644-650.

Mirek Z., Piękoś-Mirkowa H., Zając A., Zając M. 2002. Flowering plants and pteridophytes of Poland: a checklist. Instytut Botaniki PAN, Kraków, 442 pp.

Niaz I., Dawar S. 2009. Detection of seed borne mycoflora in maize (Zea mays L.). Pakistani Journal of Botany 41 (1): $443-451$.

Pitt J.I., Hocking A.D. 2009. Fungi and food spoilage. Springer, New York, 320 pp.

Pusz W. 2009. Fungi from seeds of Amaranthus spp. Phytopathologia 54: 15-21.

Sowley E.N., Dowey F.M., Shaw M.W. 2010. Persistent, symptomless, systemic, and seed-borne infection of lettuce by Botrytis cinerea. European Journal of Plant Pathology 126 (1): 61-71.

Szczęśniak E., Malicki M., Kuś D. 2009. Saxifraga nivalis L. w Karkonoszach - stan aktualny i próby wzmocnienia populacji. Acta Botanica Silesiaca 4: 107-116.

Watanabe T. 2011. Pictorial atlas of soil and seed fungi: morphologies of cultured fungi and key to species. CRC Press, Washington, $420 \mathrm{pp}$.

Weiner W., Domaradzka O. 2005. Badania odkażania nasion papryki. Inżynieria Rolnicza 9: 361-365.

$\mathrm{Xu}$ X.M., Nicholson P. 2009. Community ecology of fungal pathogens causing wheat head blight. Annual Review of Phytopathology 47: 83-109.

Załęski A. 2000. Zasady i metodyka oceny nasion w Lasach Państwowych. CIIP, Warszawa, 180 ss.

Żołnierz L., Wojtuń B., Kwiatkowski P., Matuła J. 2004. Ocena stanu populacji wybranych rzadkich gatunków roślin w Karkonoskim Parku Narodowym. Opera Corcontica 41: 229-235. 